\title{
Effects of Plant Spacing and Cultivar on Incidence of Botrytis Fruit Rot in Annual Strawberry
}

\author{
D. E. Legard, C. L. Xiao, J. C. Mertely, and C. K. Chandler, University of Florida, Gulf Coast Research and \\ Education Center, 13138 Lewis Gallagher Road, Dover 33527
}

\begin{abstract}
Legard, D. E., Xiao, C. L., Mertely, J. C., and Chandler, C. K. 2000. Effects of plant spacing and cultivar on incidence of Botrytis fruit rot in annual strawberry. Plant Dis. 84:531-538.

The effects of within-row plant spacing and cultivar on the incidence of Botrytis fruit rot (Botrytis cinerea) and marketable yield of annual strawberry were evaluated during the 1997-98 and 1998-99 seasons. Three cultivars (Camarosa, Rosa Linda, and Sweet Charlie) and four plant spacings $(23,30,38$, and $46 \mathrm{~cm})$ were evaluated. Marketable yield and the incidence of Botrytis fruit rot were determined twice weekly. Cultivar and spacing effects were analyzed for three periods each season (early, late, and whole season). In 1997-98, spacing effects were observed on weekly incidence of Botrytis rot for the late period $(P=0.0925)$ and on cumulative incidence for the whole season period $(P=0.0795)$. Further analysis of the late and whole season periods revealed a spacing effect for Camarosa $(P=0.0102)$. Spacing also had a dramatic effect on cumulative and weekly Botrytis incidence for the late and whole season periods during the 1998-99 season $(P \leq 0.0014)$, when narrower spacings had higher incidence of Botrytis than wider spacings. Marketable yields were higher at narrower spacings during the early period for both seasons. Whole season marketable yields were also higher at the narrower spacings despite higher incidence of Botrytis. There were significant differences in susceptibility among cultivars.
\end{abstract}

Additional keywords: cultural control, epidemiology, Fragaria $\times$ ananassa, plant density

Botrytis cinerea causes an internationally important preharvest and postharvest fruit rot of strawberry. In annual production of susceptible cultivars in Florida, losses to preharvest Botrytis fruit rot can be as high as $15 \%(13,14)$.

Little is known about the dynamics of Botrytis fruit rot epidemics in annual strawberry production systems. Most of the information about Botrytis fruit rot on strawberry comes from research done on perennial production systems or in the laboratory under controlled environmental conditions. Epidemics of Botrytis fruit rot are primarily initiated by conidia produced on dead strawberry leaves within the field in perennial production systems (4). Young expanding strawberry leaves are quiescently infected by the pathogen. As the leaf senesces, the pathogen colonizes the leaf tissue and sporulates (5). Temperature and wetness duration have the greatest effect on inoculum production. The optimum sporulation temperature in dead leaf tissue was approximately $18^{\circ} \mathrm{C}$, and sporulation

Corresponding author: Daniel E. Legard

E-mail: legard@ufl.edu

Florida Agricultural Experiment Station Journal Series R-07303.

Accepted for publication 31 December 1999.

Publication no. D-2000-0313-05R

(c) 2000 The American Phytopathological Society increased with longer wetness duration (21). Conidia are dispersed to flowers by air or water (24) and also mechanically by harvesting operations. Flower infections are favored by long periods of wetness (6). These infections establish quiescent mycelium in floral parts that ultimately infect and decay ripening fruit. Direct infection of fruit by conidia is not considered significant (24). After initiation of the epidemic, the pathogen sporulates on diseased flowers and fruit. These spores become important sources of secondary inocula in annual production systems where flowers are continuously produced over several months.

Botrytis fruit rot is managed with a combination of chemical, cultural, and genetic methods. Limited research has been done to characterize differences in cultivar susceptibility in annual strawberry production systems. In both perennial and annual production, no cultivar is highly resistant to Botrytis fruit rot, although differences in susceptibility exist $(16,17)$. In Florida, protectant fungicides such as captan or thiram are applied weekly and supplemented with other fungicides (i.e., iprodione) during peak flowering periods. Commercial growers in Florida use up to 24 applications of captan (2.3 to $3.4 \mathrm{~kg}$ a.i./ha) per season. In perennial systems, bloom applications of fungicides can effectively control Botrytis fruit rot (26).

Cultural practices can be changed to improve the control of Botrytis fruit rot in strawberry by reducing inoculum through sanitation or by modifying canopy microclimate to produce conditions less favorable for disease. Removal of senescent foliage reduced disease incidence slightly in an annual system (12). Commercial growers often remove senescent foliage after plant establishment. Growers also use drip instead of overhead irrigation to reduce free moisture and to prevent splash dispersal of pathogens. Growing strawberries under clear plastic tunnels also reduces leaf wetness duration and Botrytis fruit rot incidence (27). Reducing plant density (22) by establishing wider within-row plant spacings or using cultural practices that promote air circulation and rapid drying within the fruiting canopy (19) have been recommended as methods to reduce diseases that require high humidity and leaf wetness.

Limited experimental evidence supports the widespread belief that growing plants in dense stands promotes epidemics (7). Cercospora apii blight spread faster in close-spaced than wide-spaced celery (2), and the reduction in disease progress was attributed to modified microclimate. However, at commercially viable plant densities, no spacing effects were detected (23). Some cultivars of common bean have a higher incidence of white mold at higher plant densities $(20,25)$, possibly because reduced air movement within the canopy favored disease development. Plant density did not affect cereal rust severity in mixtures of spring wheat and wild oats (18).

In commercial agriculture, stand density usually is dictated by the need to optimize yield and maximize profits. In strawberry, plant spacing also is affected by the need to enter the field to regularly apply pesticides and harvest fruit. Annual strawberries typically are grown in two-row or four-row raised bed culture systems to allow for this movement. Most commercial production in Florida uses two-row beds due to high disease pressure from Botrytis fruit rot and other diseases such as anthracnose (Colletotrichum acutatum) and Phomopsis fruit rot (P. obscurans). In Florida, fruit harvested early in the season (November and December) receives a dramatically higher market price than fruit harvested late in the season. This requires growers to balance the benefits of higher planting densities and potentially higher early yields with the risk of increased disease incidence later in the season. This study was under 
1997-1998 season
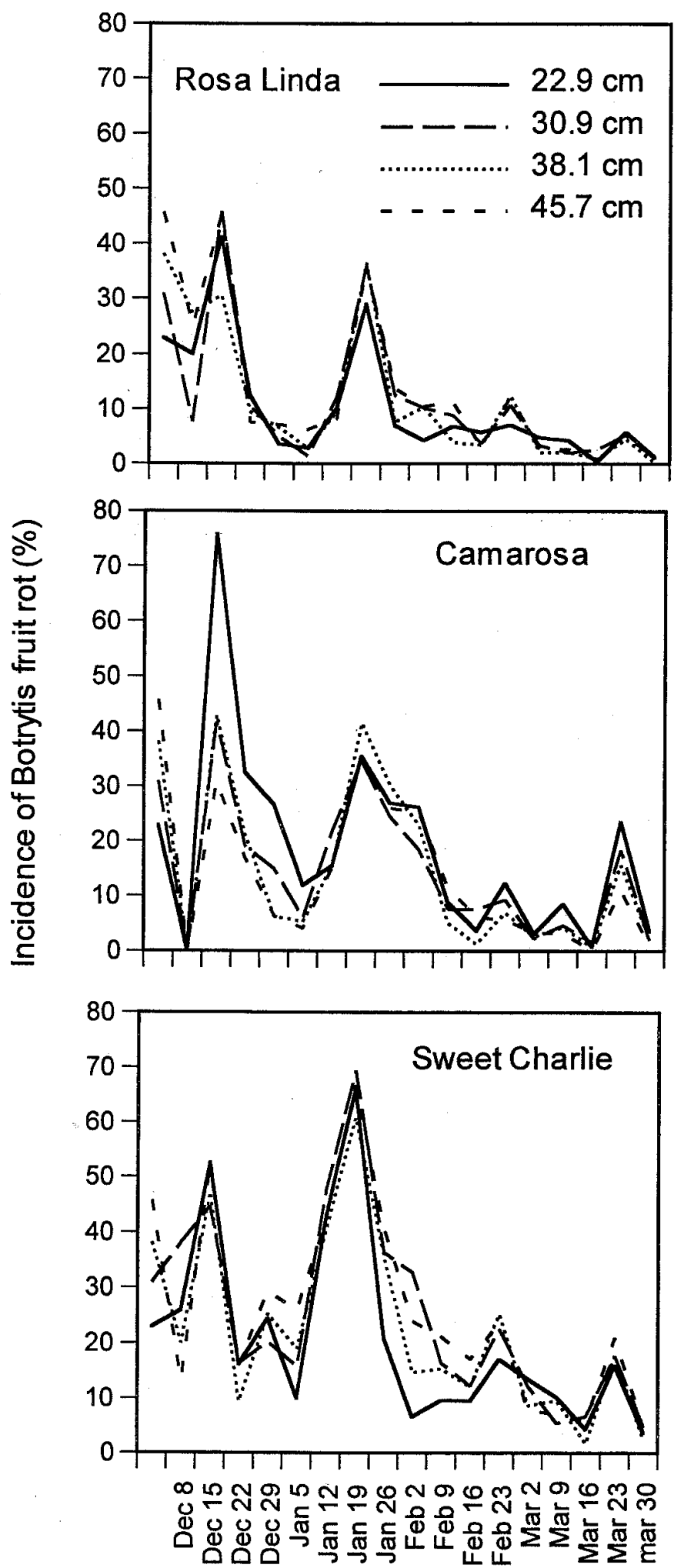

1998-1999 season
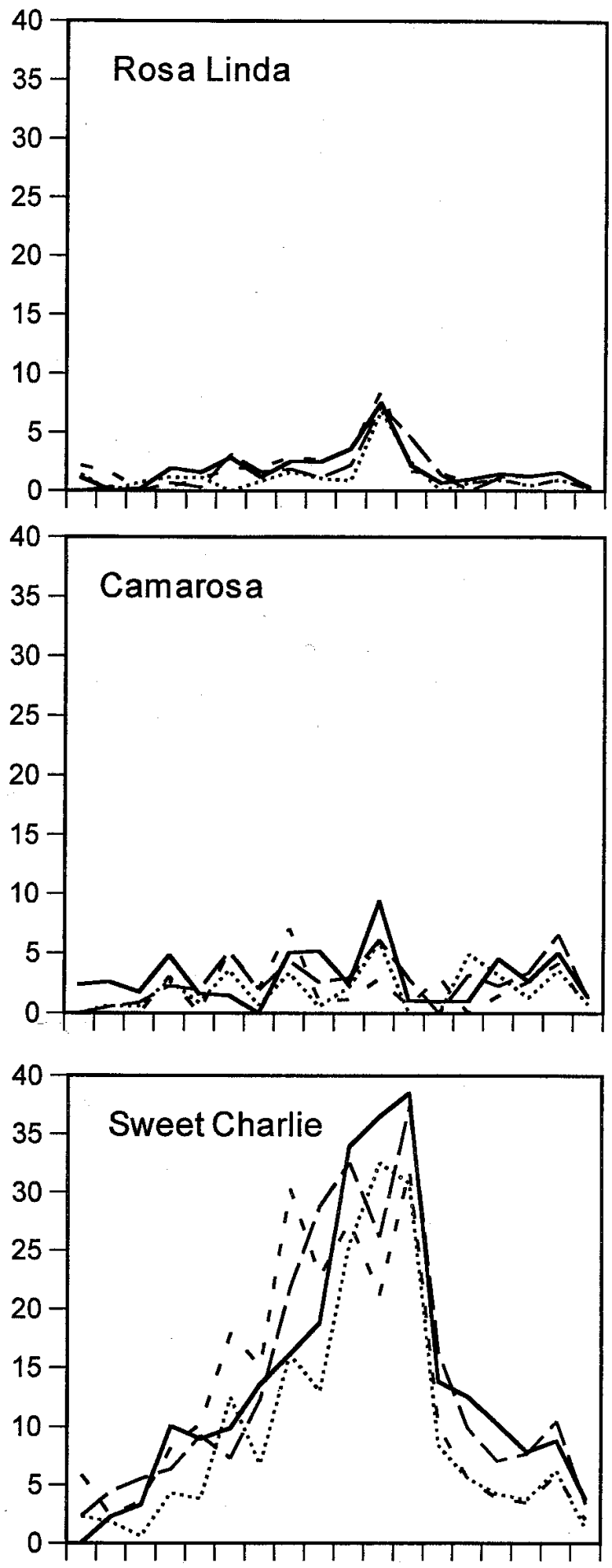

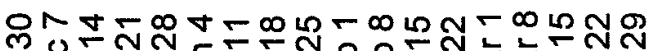

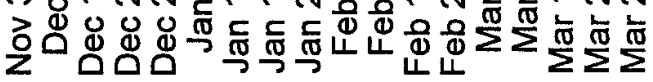

\section{Date (monday of the harvest week)}

Fig. 1. Average weekly incidence of Botrytis fruit rot during the 1997-98 and 1998-99 seasons for the three cultivars and four within-row plant spacings of strawberry. 
taken to determine the effects of withinrow plant spacing and cultivar on the incidence of Botrytis fruit rot of strawberry.

\section{MATERIALS AND METHODS}

Experiments were conducted during the 1997-98 and 1998-99 seasons at the University of Florida, Gulf Coast Research and Education Center (GCREC), at Dover. Land preparation began in the fall with a broadcast application of a 6:2:8 starter fertilizer at $570 \mathrm{~kg} / \mathrm{ha}$ and fumigation with a 98:2 mixture of methyl bromide and chloropicrin at $350 \mathrm{~kg} / \mathrm{ha}$. The experimental design was a randomized complete block with four replicates. Treatments were arranged in a $3 \times 4$ factorial design with three cultivars (Sweet Charlie, Camarosa, and Rosa Linda) and four within-row plant spacings $(22.9,30.5,38.1$, and $45.7 \mathrm{~cm})$. Sweet Charlie and Camarosa are the standard cultivars in the west-central Florida production area. Rosa Linda is a new cultivar from the University of Florida breeding program. Sweet Charlie is relatively small and low growing, Rosa Linda is medium and upright, and Camarosa is large and round. The four plant spacings represent a reasonable range that could be used commercially. In the standard $1.2 \mathrm{~m}$ between bed spacing used in Florida, plant populations would range from approximately 36,000 plants per hectare at $45.7 \mathrm{~cm}$ to approximately 72,000 plants per hectare at $22.9 \mathrm{~cm}$ within-row spacing. The typical commercial plant density in Florida is approximately 45,000 plants per hectare (38.1 cm within-row spacing).

Canadian grown green-top bare root plants were transplanted into plasticmulched raised beds on 1.22-m centers ( 71 $\mathrm{cm}$ wide and $18 \mathrm{~cm}$ high at the center and $15 \mathrm{~cm}$ high at the edge) on 7 October 1997 and 16 October 1998. Plants were placed in two offset rows per bed, spaced $23 \mathrm{~cm}$ apart between rows. Plots were $4.9 \mathrm{~m}$ long and contained $44,34,26$, or 22 plants per plot, which corresponded to 46-, 38-, 31-, and $23-\mathrm{cm}$ plant spacings. Each bed contained four plots. Plots were separated within beds by $1.2-\mathrm{m}$ open buffer areas on each end of the plot. Full-length border rows of Camarosa were planted at $38-\mathrm{cm}$ spacing on the outside beds on each side of the experiment and in 3-m plots on both ends of each bed to maintain uniform environmental conditions. Transplants were irrigated overhead for 10 days to facilitate establishment, then irrigated and fertilized by drip lines. Captan $(3.4 \mathrm{~kg} / \mathrm{ha})$ was applied weekly by tractor at 940 liters/ha to moderate the severity of Botrytis fruit rot.

Fruit were harvested twice weekly except for one harvest the final week of each season: 9 December 1997 to 30 March 1998 (33 harvests) and 30 November 1998 to 29 March 1999 (35 harvests). Fruit was graded into marketable or unmarketable on the day harvested. Marketable fruit were counted and weighed. Unmarketable fruit were sorted into number of fruit with Botrytis rot or other cull characteristics (i.e., other diseases, misshapen fruit, small fruit, etc.).

General precipitation, humidity, leaf wetness, and temperature were continuously monitored by a weather station (Adcon Telemetry, Boca Raton, FL) placed

Table 1. Analysis of variance for cumulative Botrytis fruit rot incidence and marketable yield for the different season periods during the 1997-98 and 1998-99 seasons

\begin{tabular}{|c|c|c|c|c|c|c|c|c|c|}
\hline \multirow{2}{*}{$\begin{array}{l}\text { Season } \\
\text { Source of variation }\end{array}$} & \multicolumn{3}{|c|}{ Early period ${ }^{x}$} & \multicolumn{3}{|c|}{ Late period } & \multicolumn{3}{|c|}{ Whole season } \\
\hline & df & $\mathbf{M S}^{\mathbf{y}}$ & $P>F^{\mathrm{z}}$ & df & MS & $P>F$ & df & MS & $P>F$ \\
\hline \multicolumn{10}{|l|}{$1997-98$} \\
\hline \multicolumn{10}{|c|}{ Botrytis fruit rot incidence } \\
\hline Block & 3 & 0.0135 & 0.0081 & 3 & 0.0044 & 0.0230 & 3 & 0.0047 & 0.0004 \\
\hline Cultivar & 2 & 0.3560 & 0.0001 & 2 & 0.0849 & 0.0001 & 2 & 0.1695 & 0.0001 \\
\hline Spacing & 3 & 0.0002 & 0.9736 & 3 & 0.0007 & 0.6224 & 3 & 0.0014 & 0.0795 \\
\hline Linear & 1 & 0.0003 & 0.7627 & 1 & 0.0009 & 0.3953 & 1 & 0.0031 & 0.0268 \\
\hline Quadratic & 1 & 0.0001 & 0.9385 & 1 & 0.0001 & 0.7930 & 1 & 0.0002 & 0.4889 \\
\hline Cubic & 1 & 0.0003 & 0.7281 & 1 & 0.0011 & 0.3306 & 1 & 0.0009 & 0.2239 \\
\hline Cultivar $\times$ spacing & 6 & 0.0046 & 0.1790 & 6 & 0.0012 & 0.0359 & 6 & 0.0026 & 0.0020 \\
\hline Error & 33 & 0.0029 & & 33 & 0.0012 & & 33 & 0.0006 & \\
\hline \multicolumn{10}{|l|}{ Marketable yield } \\
\hline Block & 3 & $6.19 \mathrm{E}+04$ & 0.6891 & 3 & $1.99 \mathrm{E}+06$ & 0.2346 & 3 & $1.40 \mathrm{E}+06$ & 0.3826 \\
\hline Cultivar & 2 & $8.92 \mathrm{E}+06$ & 0.0001 & 2 & $9.15 \mathrm{E}+07$ & 0.0001 & 2 & $1.17 \mathrm{E}+08$ & 0.0001 \\
\hline Spacing & 3 & $4.12 \mathrm{E}+06$ & 0.0001 & 3 & $2.01 \mathrm{E}+06$ & 0.2304 & 3 & $5.56 \mathrm{E}+06$ & 0.0132 \\
\hline Linear & 1 & $1.24 \mathrm{E}+07$ & 0.0001 & 1 & $6.0 \mathrm{E}+04$ & 0.8326 & 1 & $1.05 \mathrm{E}+07$ & 0.0085 \\
\hline Quadratic & 1 & $2.31 \mathrm{E}+04$ & 0.6704 & 1 & $5.4 \mathrm{E}+06$ & 0.0517 & 1 & $6.16 \mathrm{E}+06$ & 0.0391 \\
\hline Cubic & 1 & $2.37 \mathrm{E}+05$ & 0.1785 & 1 & $5.4 \mathrm{E}+05$ & 0.5279 & 1 & $6.24 \mathrm{E}+04$ & 0.8301 \\
\hline Cultivar $\times$ spacing & 6 & $1.50 \mathrm{E}+05$ & 0.3328 & 6 & $5.42 \mathrm{E}+05$ & 0.5279 & 6 & $1.21 \mathrm{E}+06$ & 0.5006 \\
\hline Error & 33 & $1.25 \mathrm{E}+05$ & & 33 & $1.33 \mathrm{E}+06$ & & 33 & $1.87 \mathrm{E}+07$ & \\
\hline \multicolumn{10}{|l|}{$1998-99$} \\
\hline \multicolumn{10}{|c|}{ Botrytis fruit rot incidence } \\
\hline Block & 3 & 0.0008 & 0.7239 & 3 & 0.0017 & 0.0512 & 3 & 0.0008 & 0.2487 \\
\hline Cultivar & 2 & 0.1567 & 0.0001 & 2 & 0.1843 & 0.0001 & 2 & 0.1806 & 0.0001 \\
\hline Spacing & 3 & 0.0045 & 0.0928 & 3 & 0.1001 & 0.0001 & 3 & 0.0065 & 0.0001 \\
\hline Linear & 1 & 0.0008 & 0.5175 & 1 & 0.0253 & 0.0001 & 1 & 0.0139 & 0.0001 \\
\hline Quadratic & 1 & 0.0092 & 0.0367 & 1 & 0.0004 & 0.3858 & 1 & 0.0013 & 0.1368 \\
\hline Cubic & 1 & 0.0035 & 0.1883 & 1 & 0.0044 & 0.0104 & 1 & 0.0043 & 0.0102 \\
\hline Cultivar $\times$ spacing & 6 & 0.0012 & 0.7031 & 6 & 0.0013 & 0.0650 & 6 & 0.0008 & 0.2609 \\
\hline Error & 33 & 0.0019 & & 33 & 0.0006 & & 33 & 0.0005 & \\
\hline \multicolumn{10}{|l|}{ Marketable yield } \\
\hline Block & 3 & $1.39 \mathrm{E}+04$ & 0.9915 & 3 & $5.11 \mathrm{E}+04$ & 0.9924 & 3 & $5.53 \mathrm{E}+04$ & 0.9950 \\
\hline Cultivar & 2 & $1.70 \mathrm{E}+07$ & 0.0001 & 2 & $2.18 \mathrm{E}+08$ & 0.0001 & 2 & $2.87 \mathrm{E}+08$ & 0.0001 \\
\hline Spacing & 3 & $9.31 \mathrm{E}+06$ & 0.0001 & 3 & $1.71 \mathrm{E}+07$ & 0.0001 & 3 & $4.86 \mathrm{E}+07$ & 0.0001 \\
\hline Linear & 1 & $2.79 \mathrm{E}+07$ & 0.0001 & 1 & $3.95 \mathrm{E}+07$ & 0.0001 & 1 & $1.34 \mathrm{E}+08$ & 0.0001 \\
\hline Quadratic & 1 & $4.29 \mathrm{E}+03$ & 0.9191 & 1 & $1.16 \mathrm{E}+07$ & 0.0118 & 1 & $1.21 \mathrm{E}+07$ & 0.0298 \\
\hline Cubic & 1 & $4.22 \mathrm{E}+04$ & 0.7504 & 1 & 4.44E+04 & 0.8701 & 1 & $2.60 \mathrm{E}+01$ & 0.9974 \\
\hline Cultivar $\times$ spacing & 6 & $3.54 \mathrm{E}+05$ & 0.5317 & 6 & $2.34 \mathrm{E}+06$ & 0.2320 & 6 & $4.02 \mathrm{E}+06$ & 0.1481 \\
\hline Error & 33 & 4.10E+05 & & 33 & $1.63 \mathrm{E}+06$ & & 33 & $5.32 \mathrm{E}+07$ & \\
\hline
\end{tabular}

${ }^{\mathrm{x}}$ Early period is first 8 weeks of harvests, late period is all harvests after first 8 weeks each season. Whole season includes all harvests each season.

${ }^{y}$ Mean square.

${ }^{\mathrm{z}}$ The significant probability values associated with $F$ tests. Analysis of variance was performed on arcsine square root transformed data. 
within a bed of strawberry plants. Weather data collected at GCREC-Dover from 1965 to 1995 were used to calculate 30-year averages.

Statistical analysis was performed using SAS (SAS Institute, Cary, NC). Botrytis fruit rot incidence was transformed (arcsine square root) prior to analysis. For general comparisons, analyses of variance were performed for cumulative Botrytis fruit rot incidence and marketable yield for the early period (harvests from first 8 weeks), late period (all harvests after first 8 weeks), and the whole season data sets. Botrytis fruit rot incidence was calculated as the percentage of fruit with Botrytis rot from the total number of fruit harvested during the period. Total marketable yield was the cumulative yield for all harvests during a period. Mean comparisons of cultivar effects were made by Fisher's protected least significant difference (LSD) $(P \leq 0.05)$. When significant cultivar $\times$ spacing interactions were found, analyses were performed separately for each cultivar, and variance was partitioned to test for linear, quadratic, and cubic trends.

The effects of cultivar and spacing on Botrytis incidence over time were analyzed by repeated measures analysis of variance $(8,11)$ using the SAS general linear model procedure (Proc GLM) with the repeated option. Time interactions were tested with Wilks' $\lambda$. Weekly Botrytis incidence was expressed as the average percentage of Botrytis fruit rot for the two harvests during each weekly period, except for the final week, when fruit were harvested once. Repeated measures analysis of variance was done for the early and late periods and for the whole season. When significant spacing effects were found, variance was further partitioned into linear, quadratic, and cubic components, and their significance was tested.

\section{RESULTS}

Botrytis fruit rot epidemics were severe in both seasons (Fig. 1), although the epidemic was most severe in 1997-98. Differences in the incidence of Botrytis among cultivars was highly significant during all three periods both seasons (Table 1). The ranking of cultivar susceptibility to Botrytis was consistent over all three periods (early, late, and whole season) both seasons. Sweet Charlie had the highest mean incidence each period, followed by Camarosa and Rosa Linda (Table 2). The differences in the incidence of Botrytis among cultivars was very large. Rosa Linda had $52 \%$ lower incidence of Botrytis fruit rot than Camarosa and 71 to $86 \%$ lower incidence than Sweet Charlie over the two seasons.

In the 1997-98 season, plant spacing had no effect on Botrytis incidence during the early and late periods (Table 1). However, spacing did affect $(P=0.0795)$ Botrytis incidence over the whole season. Because of significant cultivar $\times$ spacing interactions during the late and whole season periods, spacing effects during these periods were evaluated separately for each cultivar (Table 3). For Camarosa, spacing had a significant effect on the incidence of Botrytis during the late period $(P=0.0102)$ and for the whole season $(P=0.0023)$. The narrowest spacing of Camarosa had the highest incidence of Botrytis, the intermediate spacings were intermediate, and the widest spacing had the lowest incidence.
The widest spacing $(45.7 \mathrm{~cm})$ had 40 and $44 \%$ lower incidence of Botrytis than the narrowest spacing $(22.9 \mathrm{~cm})$ during the late period and the whole season, respectively, and this amounted to a 4.5 to $5.4 \%$ reduction in the incidence of Botrytis. Spacing did not affect the incidence of Botrytis for Rosa Linda or Sweet Charlie.

In the 1998-99 season, spacing had an extremely significant effect on the incidence of Botrytis for the late period and the whole season $(P=0.0001)$ (Table 1). Spacing differences in the incidence of Botrytis were also found for the early pe$\operatorname{riod}(P=0.0928)$. There were significant linear correlations $(P=0.0001)$ between spacing and the incidence of Botrytis during the late period and for the whole season (Table 1). Narrower spacings (22.9 and $30.5 \mathrm{~cm}$ ) had higher incidences of Botrytis than wider spacings (38.1 and $45.7 \mathrm{~cm}$ ) (Table 2). Although the incidence of Botrytis at the wider spacings was 26 to $42 \%$ lower than at the narrower spacings during these periods, this was a real reduction of only 1.2 to $2.1 \%$ in incidence of Botrytis.

The characteristics of Botrytis fruit rot epidemics were different each season (Fig. 1). In 1997-98, Botrytis incidence peaked once in mid-December and once in midJanuary. In 1998-99, Botrytis incidence increased until mid-February and then declined during the final 6 weeks. Weekly incidence of Botrytis on Sweet Charlie was as high as $69 \%$ in $1997-98$ and $39 \%$ in 1998-99. Weekly incidence of Botrytis was also relatively high for Camarosa in 199798, but moderate in 1998-99. Rosa Linda had moderate to low Botrytis incidence both seasons. The peaks in the incidence of Botrytis occurred at the same weeks

Table 2. Cumulative Botrytis fruit rot incidence and marketable yield for cultivar and row spacing treatments from each period during the 1997-98 and 1998-99 seasons

\begin{tabular}{|c|c|c|c|c|c|c|c|}
\hline \multicolumn{2}{|c|}{ Treatment } & \multicolumn{3}{|c|}{ 1997-98 season } & \multicolumn{3}{|c|}{ 1998-99 season } \\
\hline Cultivar & Plant spacing & Early period ${ }^{v}$ & Late period & Whole season & Early period & Late period & Whole season \\
\hline \multicolumn{8}{|c|}{ Botrytis fruit rot incidence ${ }^{w}$} \\
\hline Camarosa & & $20.81 b^{x}$ & 7.37 & 10.50 & $2.63 \mathrm{~b}$ & $2.96 \mathrm{~b}$ & $2.84 \mathrm{~b}$ \\
\hline Rosa Linda & & $12.96 \mathrm{a}$ & 3.56 & 5.07 & $1.18 \mathrm{a}$ & $1.40 \mathrm{a}$ & $1.36 \mathrm{a}$ \\
\hline \multirow[t]{5}{*}{ Sweet Charlie } & & $37.50 \mathrm{c}$ & 10.73 & 17.50 & $8.82 \mathrm{c}$ & $10.34 \mathrm{c}$ & $10.03 \mathrm{c}$ \\
\hline & $22.9 \mathrm{~cm}$ & 23.35 & 7.54 & 11.74 & 4.16 & 6.26 & 5.80 \\
\hline & $30.9 \mathrm{~cm}$ & 24.00 & 7.60 & 11.50 & 4.12 & 5.86 & 5.50 \\
\hline & $38.1 \mathrm{~cm}$ & 23.25 & 6.68 & 10.24 & 3.13 & 3.74 & 3.63 \\
\hline & $45.7 \mathrm{~cm}$ & 24.43 & 7.06 & 10.67 & 5.43 & 3.75 & 4.05 \\
\hline Orthogonal pol & , linear partition) & 0.7627 & $\mathrm{nd}^{\mathrm{y}}$ & nd & 0.5175 & 0.0001 & 0.0001 \\
\hline \multicolumn{8}{|c|}{ Marketable yield $(\mathrm{kg} / \mathrm{ha})^{\mathrm{z}}$} \\
\hline Camarosa & & 7,441 a & $20,959 \mathrm{~b}$ & $28,400 \mathrm{a}$ & $8,698 \mathrm{a}$ & $19,420 \mathrm{c}$ & $28,118 b$ \\
\hline Rosa Linda & & $5,199 \mathrm{~b}$ & $22,381 \mathrm{a}$ & $27,580 \mathrm{a}$ & $9,010 \mathrm{a}$ & $31,081 \mathrm{a}$ & $40,091 \mathrm{a}$ \\
\hline \multirow[t]{5}{*}{ Sweet Charlie } & & $5,338 \mathrm{~b}$ & $14,814 \mathrm{c}$ & $20,153 \mathrm{~b}$ & $5,862 \mathrm{~b}$ & $21,546 \mathrm{~b}$ & $27,408 \mathrm{~b}$ \\
\hline & $22.9 \mathrm{~cm}$ & 7,037 & 18,819 & 25,856 & 9,538 & 25,259 & 34,797 \\
\hline & $30.9 \mathrm{~cm}$ & 6,566 & 19,684 & 26,250 & 8,513 & 25,457 & 33,970 \\
\hline & $38.1 \mathrm{~cm}$ & 5,493 & 20,217 & 25,711 & 7,233 & 24,229 & 31,462 \\
\hline & $45.7 \mathrm{~cm}$ & 4,875 & 18,819 & 23,695 & 6,144 & 21,118 & 27,262 \\
\hline Orthogonal pol & , linear partition) & 0.0001 & 0.8326 & 0.0085 & 0.0001 & 0.0001 & 0.0001 \\
\hline
\end{tabular}

$\mathrm{v}$ Early period is first 8 weeks of harvests, late period is all harvests after first 8 weeks each season. Whole season includes all harvests that season.

${ }^{\mathrm{w}}$ Botrytis fruit rot incidence values are expressed as percentage of marketable and unmarketable fruit harvested with Botrytis rot, and have been untransformed for ease of comparison.

${ }^{x}$ Means followed by different letters within a column in each section are significantly different as determined by Fisher's protected LSD test $(P=0.05)$.

y Not determined because there was significant cultivar $\times$ spacing interaction.

${ }^{\mathrm{z}}$ Marketable yield was converted from grams per plot to kilograms per hectare. 
among the different cultivars and spacings both seasons.

Repeated measures analysis of variance indicated that cultivar significantly affected weekly incidence of Botrytis fruit rot during both the early and late periods both seasons (Table 4). No significant row spacing effect occurred during the early period each season. Spacing had an effect on the incidence of Botrytis during the late period in 1997-98 $(P=0.0952)$ and an extremely significant effect during the late period in 1998-99 $(P=0.0001)$. Over the whole season, spacing affected the incidence of Botrytis $(P=0.0014)$ only in 1998-99. The spacing effects in 1998-99 were linearly correlated with the incidence of Botrytis (Table 4), with the wider spac- ings having lower levels of Botrytis than the narrower spacings.

Time and time $\times$ cultivar interactions significantly affected weekly incidence of Botrytis during early and late periods both seasons (Table 4). Significant time $\times$ cultivar interactions indicate that Botrytis fruit rot development over time differed among cultivars over time. The cultivar $\times$ spacing

Table 3. The effects of cultivar and plant spacing on the cumulative incidence of Botrytis fruit rot for the late period and whole season during 1997-98

\begin{tabular}{|c|c|c|c|c|c|c|}
\hline & \multicolumn{6}{|c|}{ Incidence of Botrytis fruit rot ${ }^{w}$} \\
\hline & \multicolumn{3}{|c|}{ Late period $^{\mathrm{x}}$} & \multicolumn{3}{|c|}{ Whole season ${ }^{y}$} \\
\hline & Camarosa & Rosa Linda & Sweet Charlie & Camarosa & Rosa Linda & Sweet Charlie \\
\hline \multicolumn{7}{|l|}{ Spacing $(\mathrm{cm})$} \\
\hline 22.9 & 10.01 & 3.19 & 9.4 & 13.68 & 4.89 & 16.64 \\
\hline 30.9 & 7.51 & 3.82 & 11.47 & 10.65 & 5.29 & 18.57 \\
\hline 38.1 & 6.37 & 3.39 & 10.27 & 9.49 & 4.74 & 16.48 \\
\hline 45.7 & 5.58 & 3.84 & 11.76 & 8.19 & 5.37 & 18.47 \\
\hline \multicolumn{7}{|c|}{$\begin{array}{l}\text { Source of variation } \\
\left(P>F^{z}\right)\end{array}$} \\
\hline Spacing & 0.0102 & 0.4986 & 0.6578 & 0.0023 & 0.6813 & 0.4978 \\
\hline Linear & 0.0017 & 0.2801 & 0.3946 & 0.0003 & 0.6067 & 0.5485 \\
\hline Quadratic & 0.3105 & 0.8053 & 0.8761 & 0.3298 & 0.7620 & 0.9900 \\
\hline Cubic & 0.7301 & 0.3059 & 0.3836 & 0.5202 & 0.3081 & 0.1739 \\
\hline
\end{tabular}

Table 4. Repeated measures analysis of variance describing effects of row spacing and cultivar on weekly incidence of Botrytis fruit rot of strawberry during three periods (early, late, and whole season) of the 1997-98 and 1998-99 seasons

\begin{tabular}{|c|c|c|c|c|c|c|c|c|c|}
\hline \multirow{2}{*}{$\begin{array}{l}\text { Season } \\
\text { Source of variation }\end{array}$} & \multicolumn{3}{|c|}{ Early period $^{\mathrm{w}}$} & \multicolumn{3}{|c|}{ Late period } & \multicolumn{3}{|c|}{ Whole season } \\
\hline & df & $\mathbf{M S}^{\mathbf{x}}$ & $P>F^{y}$ & df & MS & $P>F$ & df & MS & $P>F$ \\
\hline \multicolumn{10}{|l|}{$1997-98$} \\
\hline Block & 3 & 0.0766 & 0.1738 & 3 & 0.0465 & 0.0224 & 3 & 0.0735 & 0.0372 \\
\hline Cultivar & 2 & 1.9779 & 0.0001 & 2 & 0.8296 & 0.0001 & 2 & 2.6153 & 0.0001 \\
\hline Spacing & 3 & 0.0328 & 0.5281 & 3 & 0.0294 & 0.0952 & 3 & 0.0061 & 0.8501 \\
\hline Linear & 1 & 0.0447 & 0.3179 & 1 & 0.0011 & 0.7684 & 1 & 0.0146 & 0.4342 \\
\hline Quadratic & 1 & 0.0085 & 0.6603 & 1 & 0.0057 & 0.5094 & 1 & 0.0001 & 0.9552 \\
\hline Cubic & 1 & 0.045 & 0.3162 & 1 & 0.0813 & 0.0166 & 1 & 0.0038 & 0.6873 \\
\hline Cultivar $\times$ spacing & 6 & 0.1098 & 0.0402 & 6 & 0.0246 & 0.1049 & 6 & 0.1058 & 0.0018 \\
\hline Error & 33 & 0.0435 & & 33 & 0.0127 & & 33 & 0.0232 & \\
\hline Time effects & & Wilks' $\lambda^{z}$ & & & Wilks' $\lambda$ & & & Wilks' $\lambda$ & \\
\hline Time & 7 & 0.0608 & 0.0001 & 7 & 0.0333 & 0.0001 & 7 & 0.0105 & 0.0001 \\
\hline Time $\times$ block & 21 & 0.6483 & 0.9027 & 21 & 0.3762 & 0.2153 & 21 & 0.1380 & 0.4017 \\
\hline Time $\times$ cultivar & 14 & 0.1193 & 0.0001 & 14 & 0.0953 & 0.0001 & 14 & 0.0118 & 0.0001 \\
\hline Time $\times$ spacing & 21 & 0.3621 & 0.0769 & 21 & 0.2317 & 0.0087 & 21 & 0.1153 & 0.2486 \\
\hline Time $\times$ cultivar $\times$ spacing & 42 & 0.2228 & 0.2516 & 42 & 0.0879 & 0.0064 & 42 & 0.0167 & 0.1781 \\
\hline 1998-99 & & MS & & & MS & & & MS & \\
\hline Block & 3 & 0.0135 & 0.5911 & 3 & 0.0322 & 0.0381 & 3 & 0.0179 & 0.3546 \\
\hline Cultivar & 2 & 1.0707 & 0.0001 & 2 & 3.5636 & 0.0001 & 2 & 4.3893 & 0.0001 \\
\hline Spacing & 3 & 0.0366 & 0.1759 & 3 & 0.1105 & 0.0001 & 3 & 0.1042 & 0.0014 \\
\hline Linear & 1 & 0.0020 & 0.7576 & 1 & 0.2702 & 0.0001 & 1 & 0.1742 & 0.0023 \\
\hline Quadratic & 1 & 0.0848 & 0.0523 & 1 & 0.0051 & 0.4863 & 1 & 0.0612 & 0.0588 \\
\hline Cubic & 1 & 0.0231 & 0.3016 & 1 & 0.0563 & 0.0254 & 1 & 0.0773 & 0.0349 \\
\hline Cultivar $\times$ spacing & 6 & 0.0058 & 0.9440 & 6 & 0.0108 & 0.4108 & 6 & 0.0087 & 0.7698 \\
\hline Error & 33 & 0.0209 & & 33 & 0.0102 & & 33 & 0.0159 & \\
\hline Time effects & & Wilks' $\lambda$ & & & Wilks' $\lambda$ & & & Wilks' $\lambda$ & \\
\hline Time & 7 & 0.0889 & 0.0001 & 7 & 0.0311 & 0.0001 & 7 & 0.0199 & 0.0001 \\
\hline Time $\times$ block & 21 & 0.5464 & 0.6264 & 21 & 0.3712 & 0.3613 & 21 & 0.0702 & 0.0926 \\
\hline Time $\times$ cultivar & 14 & 0.1823 & 0.0001 & 14 & 0.0318 & 0.0001 & 14 & 0.0092 & 0.0001 \\
\hline Time $\times$ spacing & 21 & 0.4784 & 0.3778 & 21 & 0.3177 & 0.1801 & 21 & 0.1219 & 0.4502 \\
\hline Time $\times$ cultivar $\times$ spacing & 42 & 0.2948 & 0.6105 & 42 & 0.2096 & 0.7037 & 42 & 0.0358 & 0.8594 \\
\hline
\end{tabular}

${ }^{\text {w }}$ The early period is the first 8 weeks of harvests and the late period is for all harvests after the first 8 weeks each season. The whole season period includes all harvests each season.

${ }^{x}$ Mean square.

y The significant probability values associated with the $F$ tests. Analysis of variance was performed on arcsine square root transformed data.

${ }^{\mathrm{z}}$ Wilks' $\lambda$ statistic is used to test time interactions. 
interaction from the repeated measures analysis was significant for the early period in 1997-98 (Table 4). Unexpectedly, the interaction was primarily due to a significant spacing effect for Camarosa during the first month of the season. A significant cultivar $\times$ spacing interaction was also found for the whole season in 1997-98. No cultivar $\times$ spacing or time $\times$ spacing interactions occurred in 1998-99 (Table 4).

The general harvesting patterns shown by marketable yield were dramatically season (Fig. 2). Higher temperatures in 1998-99 caused the first peak harvest to occur 2 weeks earlier than in 1997-98. The second peak harvest in 1998-99 was also extremely early (18 January) and did not produce much fruit. The third peak occurred during March of the 1998-99 season and accounted for the majority of fruit influenced by weather conditions each

harvested. A third peak did not occur in 1997-98.

Cultivar effects on total marketable yield were extremely significant $(P<0.0001)$ during the early and late periods both seasons (Table 1). In 1997-98, Camarosa had significantly higher marketable yield than the other cultivars during the early period, and Rosa Linda had the highest yields during the late period (Table 2). During the 1998-99 season, the yield of Rosa Linda was significant higher than other cultivars during both early and late periods. Sweet Charlie had the lowest marketable yield during the early period both seasons despite the high early yield characteristics of the cultivar (9).

Marketable yields were affected by plant spacing during the early period and whole season in 1997-98 and during all three periods in 1998-99 (Table 1). Plant spacing
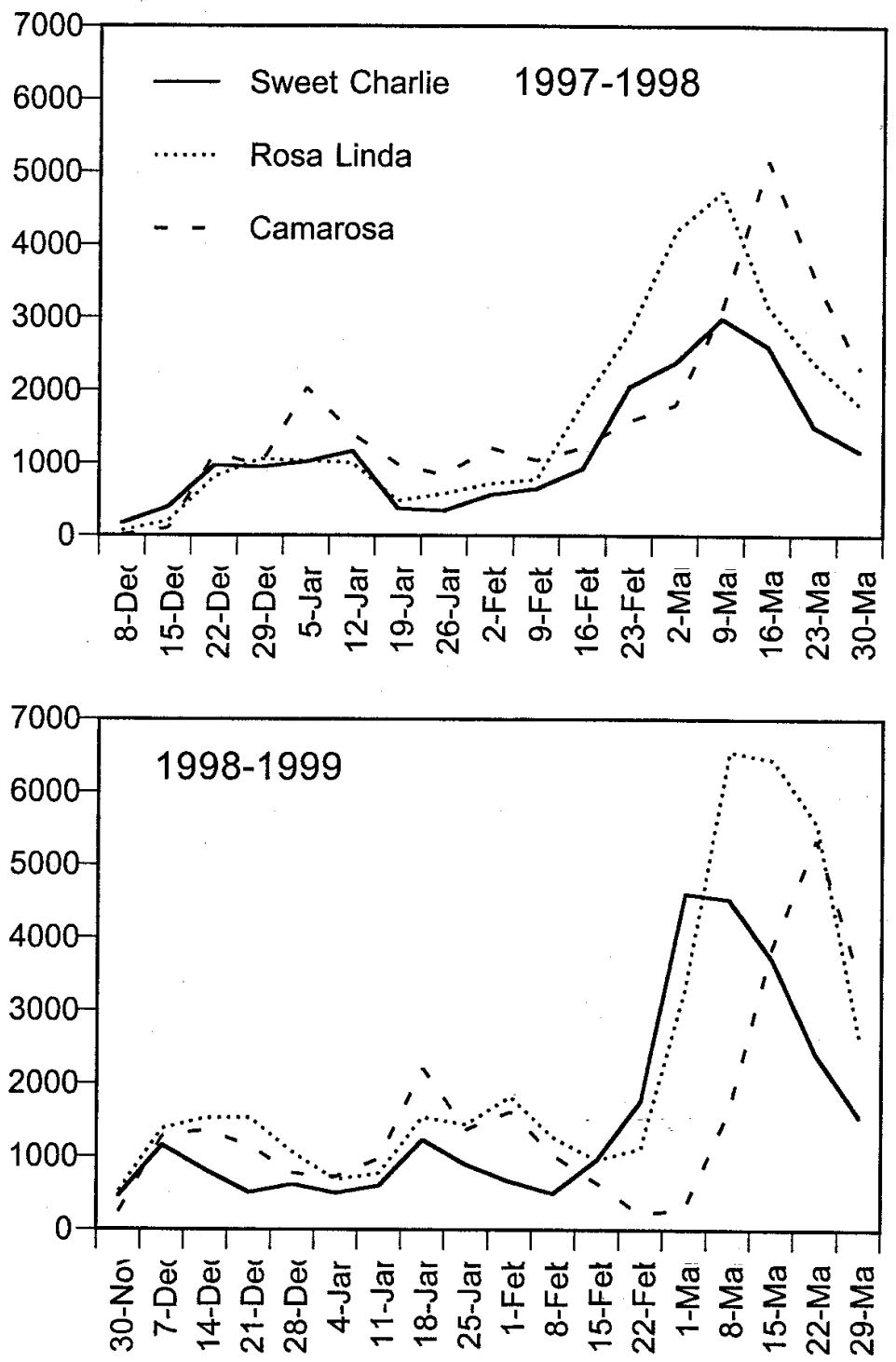

\section{Date}

Fig. 2. Weekly marketable yields averaged from four within-row spacings for the 1997-98 and 199899 seasons. had a highly significant linear correlation with marketable yield both seasons. Higher marketable yield occurred at narrower spacings than at wider spacings during the early period and whole season in 1997-98 and during all three periods in 1998-99 (Table 2). Marketable yields at the widest spacing $(45.7 \mathrm{~cm})$ were 31 and $34 \%$ lower than at the narrowest spacing $(22.9 \mathrm{~cm})$ for the early period in 1997-98 and 1998-99, respectively. Marketable yields at the 45.7 $\mathrm{cm}$ spacing were 7 and $22 \%$ lower than at the $22.9-\mathrm{cm}$ spacing for the whole season in 1997-98 and 1998-99, respectively.

Weather conditions during the two growing seasons were markedly different (Fig. 3). Precipitation was $68 \mathrm{~cm}$ higher than the 30-year average in 1997-98 and 26 cm lower in 1998-99. Average temperatures were marginally higher than the 30 year average in $1997-98\left(18.3^{\circ} \mathrm{C}\right.$ versus $18.1^{\circ} \mathrm{C}$ ) but substantially higher in 1998-99 $\left(19.8^{\circ} \mathrm{C}\right)$. Interestingly, the average daily leaf wetness duration was higher during 1998-99 (11.9 $\mathrm{h}$ versus $7.7 \mathrm{~h}$ ) despite the lower precipitation that season (Fig. 3).

\section{DISCUSSION}

Wider within-row plant spacing reduced the incidence of Botrytis fruit rot compared with narrower spacings. Levels of susceptibility to Botrytis fruit rot differed among the three cultivars evaluated in this study. Sweet Charlie had the highest mean incidence, followed by Camarosa and Rosa Linda. Plant spacing also affected marketable yield significantly. Narrower spacings produced higher yields during the early period and whole season than did the wider spacings.

Plant spacing may affect Botrytis fruit rot in several ways (7). Direct effects on host density include changes in the number of target hosts available to intercept inoculum and the spatial relationship between the hosts and spore dispersal gradients. Plant density can affect the splashdispersal of conidia of Colletotrichum acutatum in strawberry (3). Because conidia of $B$. cinerea are primarily wind dispersed, the effect of plant density on spore dispersal and deposition would likely be diminished compared with $C$. acutatum. Indirect effects also may cause a reduction in disease. Changes in plant size due to spacing may affect fungicide application and harvesting efficiency. Increased plant density could reduce the efficacy of fungicide applications by obstructing plant coverage. Because captan was applied weekly during the season, the increase in Botrytis incidence with tighter plant spacing could have been related to reduced fungicide coverage. Increased plant density also could affect fruit harvest late in the season, when plants were larger and harvest was more difficult (1). In narrower plant spacings, more fruit may escape timely harvesting and contribute to increased levels of inoculum. Modification of microclimate 
also has been suggested as the cause of disease reduction from wider plant spacings in other host-pathosystems $(2,7,15)$; however, it is extremely difficult to evaluate the influence of canopy microclimate on disease. English et al. (10) found that removal of leaves around grape clusters reduced Botrytis bunch rot (B. cinerea), but differences in microclimate variables within the canopies were not sufficient to explain the control.

Although spacing affected the weekly incidence of Botrytis fruit rot during the late period both seasons, the spacing effect was cubically correlated with incidence during the 1997-98 season and linearly correlated during the 1998-99 season. Environmental factors may be the primary cause of differences in spacing effect between the two seasons (Fig. 1). Mean temperatures were lower the first season $\left(18.3^{\circ} \mathrm{C}\right)$ than during the second season $\left(19.8^{\circ} \mathrm{C}\right)$. Precipitation was also dramatically different in frequency and accumulation. Cumulative precipitation was much higher during the 1997-98 season $(15.5 \mathrm{~cm})$ than during the $1998-99$ season $(1.9 \mathrm{~cm})$, and there was a total of 55 significant rain events $(\geq 0.025$ $\mathrm{cm} /$ day) the first season compared with only 30 the second season.

We hypothesize that the extreme precipitation events during the 1997-98 season could have masked the effect of plant spacing on the incidence of Botrytis and caused an overall increase in disease regardless of spacing. The cumulative incidence of Botrytis fruit rot during the 199798 season was double that of the 1998-99 season. Precipitation is important in the sporulation and dispersal of many pathogens. Frequent rains could have increased the splash dispersal of inoculum, possibly overwhelming the advantageous effects of wider plant spacing on airborne spore dispersal. Because infection of flowers and fruit, and subsequently inoculum production, are favored by increased wetness duration $(6,21)$, frequent precipitation could have diminished the effect of spacing on wetness duration and other microclimatic conditions within the canopy. Although the average daily wetness duration recorded outside the canopy was higher during the second season $(11.92 \mathrm{~h}$ versus $7.68 \mathrm{~h}$ ), an external sensor cannot accurately estimate the effect of precipitation on leaf wetness duration within the canopy. The relatively large number of infected fruit in 1997-98 probably contributed to increased production of inoculum. High levels of airborne and splash-dispersed inoculum would increase the level of interplot interference and diminish the benefits of wider plant spacing. Therefore, high levels of rainfall during the 1997-98 season could have overwhelmed the beneficial effects of wider spacing on the incidence of Botrytis.

The incidence of Botrytis fruit rot during the early period was not affected by plant spacing either season. This was expected, since strawberry plants in annual production systems are small early in the season. In Florida, small runner-produced plants grown in Canadian nurseries are transplanted into fruiting fields in October. The plants grow and produce new foliage and flowers throughout the season. The incidence of Botrytis fruit rot is most likely to be affected by plant spacing in February and March, when plants become large and the canopy closes, and this is when significant spacing effects occurred on Camarosa in 1997-98 and on all cultivars in 1998-99.
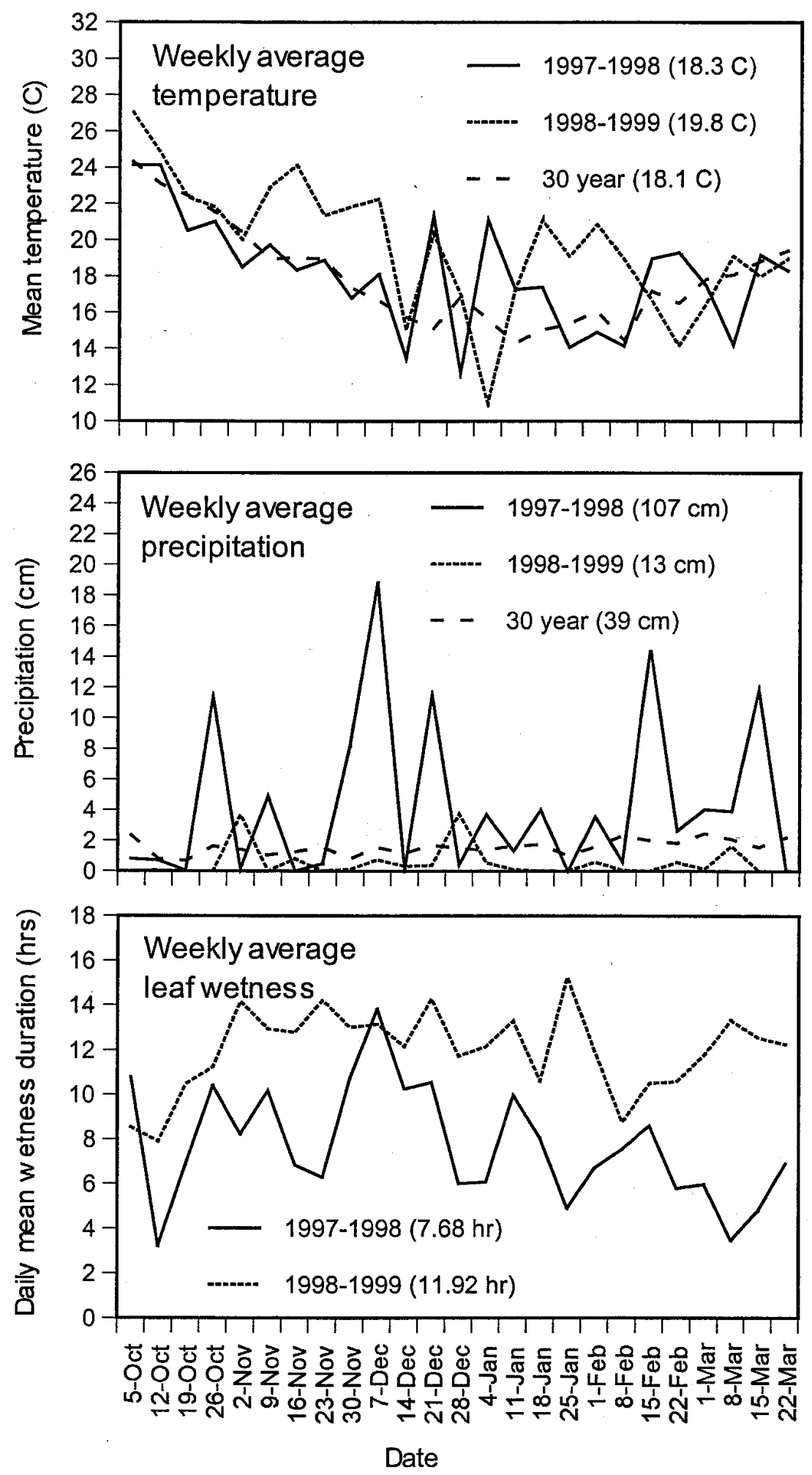

Fig. 3. Average weekly temperatures, precipitation, and leaf wetness duration (hours) for the 1997-98 and 1998-99 seasons. The 30-year average temperature and precipitation from 1965 to 1995 also are shown. 
Spacing had a significant effect on the cumulative incidence of Botrytis only for cultivar Camarosa during the late period $(P$ $=0.0102)$ and the whole season $(P=$ $0.0023)$ in 1997-98 when cultivars were analyzed separately due to cultivar $x$ spacing interactions. The cumulative incidence of Botrytis was not affected by spacing for either Rosa Linda or Sweet Charlie during these periods. This difference could be explained by the variation in plant habits among the cultivars. Camarosa has the largest growth habit of the three cultivars, and this would cause a more severe crowding of the plant canopy at the narrower plant spacings. However, the incidence of Botrytis was affected by spacing for all three cultivars during the late period and whole season in 1998-99.

Botrytis fruit rot incidence was strongly affected by cultivar both seasons. Sweet Charlie was the most susceptible cultivar evaluated in this study and is grown extensively in Florida (40 to $50 \%$ of acreage) and other subtropical areas. This cultivar is preferred by growers due to its ability to produce high-quality, good-flavored, early season fruit and its high level of resistance to anthracnose fruit rot (C. acutatum) (9). Growers frequently suffer high yield losses to Botrytis fruit rot when using this cultivar and rely heavily on fungicides to minimize losses. Camarosa is the other main cultivar grown in Florida (30 to $40 \%$ of acreage). Camarosa is less susceptible to Botrytis than Sweet Charlie but does not normally produce high yield in the early season and is extremely susceptible to anthracnose fruit rot. Rosa Linda was the cultivar least susceptible to Botrytis fruit rot. This cultivar also is less susceptible to anthracnose fruit rot than Camarosa, although it is not as resistant as Sweet Charlie. Rosa Linda appears to be a cultivar that should be considered by growers who wish to minimize fruit rots and maximize marketable yields.

To increase profits, growers try to maximize marketable yields for both the high-value early period and the whole season. For winter strawberry producers, prices during the early part of the season are often two to five times higher than during the rest of the season. Using narrower plant spacings can significantly increase early yield, although Botrytis fruit rot incidence may be increased later in the season. Despite the higher incidence of Botrytis fruit rot at narrower spacings, marketable yields were still higher than at wider spacings. Higher profits from increased early and total marketable yield at narrower spacings are somewhat offset by the increased costs associated with using more plants. The average cost of transplants used in Florida is approximately $\$ 80$ per 1,000 . There are 27,000 more plants per hectare at the narrowest spacing (22.9 $\mathrm{cm})$ than at the industry standard (38.1 $\mathrm{cm})$, and this represents an increase in plant costs of $\$ 2,160$ per hectare. When narrow plant spacings are used to increase early marketable yields, growers should consider using less-susceptible cultivars such as Camarosa or Rosa Linda, although even highly susceptible cultivars like Sweet Charlie can produce high marketable yields at narrow spacings.

\section{ACKNOWLEDGMENTS}

We thank D. Wenzel, A. Whidden, K. Burke, A. Turgeau, L. Smith, S. Staton, and J. Sumler for their valuable assistance during this study.

\section{LITERATURE CITED}

1. Albregts, E. E., and Chandler, C. K. 1995. Plant density and cultivar effects on fruiting response of strawberry. Soil Crop Sci. Soc. Fla. Proc. 54:83-86.

2. Berger, R. D. 1975. Disease incidence and infection rates of Cercospora apii in plant spacing plots. Phytopathology 65:485-487.

3. Boudreau, M. A., and Madden, L. V. 1995. Effect of strawberry density on dispersal of Colletotrichum acutatum by simulated rain. Phytopathology 85:934-941.

4. Braun, P. G., and Sutton, J. C. 1987. Inoculum sources of Botrytis cinerea in fruit rot of strawberries in Ontario. Can. J. Plant Pathol. 9:1-5.

5. Braun, P. G., and Sutton, J. C. 1988. Infection cycles and population dynamics of Botrytis cinerea in strawberry leaves. Can. J. Plant Pathol. 10:133-141.

6. Bulger, M. A., Ellis, M. A., and Madden, L. V. 1987. Influence of temperature and wetness duration on infection of strawberry flowers by Botrytis cinerea and disease incidence of fruit originating from infected flowers. Phytopathology 77:1225-1230.

7. Burdon, J. J., and Chilbers, G. A. 1982. Host density as a factor in plant disease ecology. Annu. Rev. Phytopathol. 20:143-166.

8. Campbell, C. L., and Madden, L. V. 1990. Statistical comparison of disease progress curves and descriptive parameters. Section 8.5, pages 194-201 in: Introduction to Plant Disease Epidemiology. John Wiley \& Sons, New York.

9. Chandler, C. K., Albregts, E. E., Howard, C. M., and Brect, J. K. 1997. Sweet Charlie strawberry. HortScience 32:1132-1133.

10. English, J. T., Thomas, C. S., Marois, J. J., and Gubler, W. D. 1989. Microclimates of grapevine canopies associated with leaf removal and control of Botrytis bunch rot. Phytopathology 79:395-401.

11. Gill, J. L. 1978. Design and Analysis of Ex- periments in the Animal and Biomedical Sciences. Vol. 2. Iowa State University, Ames.

12. Legard, D. E., Bartz, J. A., and Chandler, C. K. 1997. The control of strawberry diseases by sanitation. Int. Strawberry Sympos. 3rd. Acta Hortic. 439:917-922.

13. Legard, D. E., and Chandler, C. K. 1998. Evaluation of fungicides to control Botrytis fruit rot of Strawberry, 1997. Fungic. Nematicide Tests 53:121.

14. Legard, D. E., and Chandler, C. K. Evaluation of fungicides to control Botrytis fruit rot of strawberry, 1998. Fungic. Nematicide Tests. In press.

15. Maloy, O. C. 1993. Modifying the environment. Chapter 14, pages 197-213 in: Plant Disease Control: Principles and Practice. John Wiley \& Sons, New York.

16. Mass, J. L., and Smith, W. L., Jr. 1978. 'Earliglow', a possible source of resistance to Botrytis fruit rot in strawberry. HortScience 13:275-276.

17. Olcott-Reid, B., and Moore, J. N. 1995. Field reactions of strawberry cultivars and selections to anthracnose fruit rot, leather rot and gray mold in Arkansas. Fruit Var. J. 49:4-13.

18. Pfleeger, T. G., and Mundt, C. C. 1998. Wheat leaf rust severity as affected by plant density and species proportion in simple communities of wheat and wild oats. Phytopathology 88:708-714.

19. Pritts, M., Handley, D., and Walker, C. 1998 Strawberry Production Guide for the Northeast, Midwest, and Eastern Canada. Northeast Regional Agricultural Engineering Service, Publ. NRAES-88, Ithaca, NY.

20. Saindon, G., Huang, H. C., and Kozub, G. C. 1995. White-mold avoidance and agronomic attributes of upright common beans grown at multiple planting densities in narrow rows. J. Am. Soc. Hortic. Sci. 120:843-847.

21. Sosa-Alvarez, M., Madden, L. V., and Ellis, M. A. 1995. Effects of temperature and wetness duration on sporulation of Botrytis cinerea on strawberry leaf residues. Plant Dis. 79:609-615.

22. Strand, L. L. 1994. Integrated Pest Management for strawberries. University of California, Division of Agriculture and Natural Resources, Publ. 3351. Oakland, CA.

23. Strandberg, J. O., and White, J. M. 1978. Cercospora apii damage of celery - Effects of plant spacing and growth on raised beds. Phytopathology 68:223-226.

24. Sutton, J. C. 1990. Epidemiology and management of Botrytis leaf blight of onion and gray mold of strawberry: A comparative analysis. Can. J. Plant Pathol. 12:100-110.

25. Tu, J. C. 1989. Management of white mold of white beans in Ontario. Plant Dis. 73:281285.

26. Wilcox, W. F., and Seem, R. C. 1994. Relationship between strawberry gray mold incidence, environmental variables, and fungicide applications during different periods of the fruiting season. Phytopathology 84:264-270.

27. Xiao, C. L., Chandler, C. K., Price, J. F., and Legard, D. E. 1999. Comparative study on epidemics of strawberry fruit diseases under plastic tunnel and field production systems in Florida. (Abstr.) Phytopathology 89:S86. 